\title{
Sistem Berbasis Pengetahuan Untuk Pencarian Alternatif Obat Yang Berkhasiat Sama
}

\author{
Fatma Indriani \\ Universitas Lambung Mangkurat \\ f.indriani@unlam.ac.id
}

\begin{abstract}
Abstrak
Pada makalah ini dipaparkan sistem berbasis pengetahuan yang mampu mencari alternatif obat bermerek yang memiliki khasiat yang sama. Sistem ini bermanfaat membantu pasien, apoteker, maupun dokter menentukan pengganti suatu obat yang tidak tersedia. Pertama-tama, pengetahuan diakuisisi dari pakar dan direpresentasikan secara formal. Dari tahap ini, yang representasi pengetahuan meliputi data lengkap obat dari katalog, serta keterkaitan antar nama indikasi, antar nama kandungan, antar nama kontraindikasi, dan antar nama efek samping. Keterkaitan ini direpresentasikan sebagai graf tak berarah. Sedangkan mekanisme pencarian adalah dengan membandingkan kedekatan tiap unsur dari keempat petunjuk penggunaan obat tersebut terhadap query pengguna. Tahap kedua adalah implementasi sistem dengan tool expert system CLIPS. Basis pengetahuan bersumber dari salah satu indeks farmakoterapi dari buku ISO (Informasi Spesialite Obat) Indonesia. Tahap terakhir adalah pengujian sistem. Sistem diujicobakan dengan berbagai query masukan, dan keluaran sistem dibandingkan dengan jawaban pakar. Dari hasilnya didapat bahwa sistem dapat menampilkan obat pengganti dengan relevansi 95\%. Akan tetapi nilai relevansi ini dapat ditingkatkan dengan perbaikan basis pengetahuan.
\end{abstract}

Kata kunci: Sistem Berbasis Pengetahuan, Sistem Pakar, Farmakologi, Obat-obatan, CLIPS

\begin{abstract}
This paper presented a knowledge-based system that is able to suggest other drugs for alternatives to the input drugs. This system would be useful to suggest replacement if a certain drug is not available or too expensive. The first step is knowledge acquisition from experts, then knowledge representation. The representation consists of data from the catalog of drugs, as well as the relations between indications, between active ingredients, between contraindications, and between side effects. These relations are represented as undirected graph. Next step is the implementation of the system with expert system tool CLIPS. The knowledge base is sourced from ISO (Spesialite Drug Information) Indonesia--a drug catalog in Indonesia. The last step is testing and validation. The system tested with various query input which compared to experts' answer. From the results obtained, the system can find drug replacement with the relevance score of $95 \%$.
\end{abstract}

Keywords: Knowledge Based System, Expert System, Drug, CLIPS

\section{Pendahuluan}

Banyak sekali obat yang beredar di Indonesia dewasa ini. Sudah ada beberapa lembaga yang menerbitkan data tersebut secara berkala, salah satunya Ikatan Sarjana Farmasi Indonesia yang menerbitkan buku ISO Indonesia (Informasi Spesialite Obat Indonesia) dalam bentuk klasifikasi indeks farmakoterapinya, yaitu khasiat menurut zat utama dalam obat [1]. Klasifikasi ini bertujuan untuk mempermudah dokter, apoteker, dan khalayak umum mencari informasi tentang jenis atau merek obat tertentu. Klasifikasi lain, yaitu berdasarkan abjad merek atau nama generik.

Ada beberapa permasalahan terkait kebutuhan informasi akan obat-obatan bermerek. Dari sisi konsumen, pasien mengonsumsi obat hanya berdasar resep dokter tanpa mengetahui apa efeknya atau manfaatnya. Bahkan pada kasus ringan tertentu, sakit yang diderita tidak diberitahukan [2], baik pada penderita maupun keluarganya. Sedangkan di pihak dokter, ingin 
mengetahui informasi tentang suatu merek obat yang jarang dipakai atau belum pernah didengarnya. Obat baru senantiasa bermunculan di pasar dan beberapa obat yang lama ditarik dari peredaran sehingga informasi ini berubah dari tahun ke tahun.

Permasalahan kedua, yaitu substitusi obat. Substitusi obat diperlukan jika obat yang dicari mahal atau sedang tidak ada di stok. Secara umum, obat tertentu biasanya bisa digantikan oleh obat lain jika memiliki khasiat yang sama. Untuk mengetahui hal ini perlu dokter atau ahli obat-obatan tentang informasi suatu obat, termasuk indikasi, kandungan, dan kontra-indikasinya, serta kondisi personal pasien (lemah jantung, hamil/menyusui, dan lain-lain). Akan tetapi, bahkan orang ahli pun tidak mungkin tahu semua jenis obat yang beredar. Biasanya yang digunakan sebagai referensi adalah edisi terbaru dari buku indeks klasifikasi obat seperti ISO Indonesia.

Jika dibangun aplikasi konvensional untuk menangani data obat-obatan, permasalahan pertama mudah diselesaikan. Sudah banyak penelitian yang memaparkan sistem informasi obat, diantaranya [3] [4] [5] [6] [7]. Di samping itu, sistem informasi yang memberikan dukungan keputusan yaitu pengadaan obat [8] serta pemilihan suplier obat [9]

Untuk permasalahan yang kedua, penyelesaiannya tidak pasti dan bergantung banyak faktor, sehingga perlu dicari kaitan antar data serta aturan-aturan substitusi obat. Masalah ini cocoknya diselesaikan dengan sistem berbasis pengetahuan. Makalah ini memaparkan pendekatan dengan sistem berbasis pengetahuan untuk menentukan substitusi obat.

\section{Metode Penelitian}

Menurut [10], sistem pakar adalah sistem yang secara umum bekerja dengan cara mengaplikasikan rule of thumb pada suatu pengetahuan yang direpresentasikan secara formal, tanpa menggunakan metode-metode algoritmik atau statistik. Sistem pakar bertujuan untuk memecahkan masalah pada ranah tertentu. Sedangkan sistem berbasis pengetahuan lebih umum dari sistem pakar [11], yaitu sistem yang bekerja pada pengetahuan direpresentasikan secara formal.

Karakteristik sistem pakar antara lain, mencoba menyimulasikan nalar manusia, menggunakan heuristik, serta melakukan inferensi pada basis pengetahuan. Menyimulasikan nalar manusia, yaitu berusaha mengikuti langkah-langkah berpikir pakar dalam menyelesaikan masalah. Kemudian heuristik yang digunakan dalam menyelesaikan masalah didapat dari pengalaman pakar. Sedangkan bagian yang menyimpan pengetahuan dipisah dengan bagian yang menangani inferensi. Pada makalah ini akan dipaparkan langkah-langkah yang dilakukan meliputi:

1. Analisis pengetahuan, terdiri dari:

a. elisitasi pengetahuan

b. representasi pengetahuan

c. manipulasi pengetahuan (inferensi)

2. Implementasi dan Pengujian sistem

\section{Analisis Pengetahuan}

\subsection{Representasi Pengetahuan}

Dari wawancara dengan pakar, didapat pengetahuan sebagai berikut:

1. Dalam buku ISO Indonesia, obat-obat dikelompokkan berdasarkan indeks farmakoterapi. Sebagian dapat dilihat pada Gambar 1. Tiap indeks (yaitu daun pohon) memiliki obat-obat di dalamnya, yaitu obat-obat yang merupakan kelompok indeks farmakoterapi tersebut (instance). Obat-obat yang sejenis dikelompokkan ke dalam kelompok indeks yang sama. Dengan demikian, penderita sistem pencernaan, misalnya, hanya menggunakan obat-obat sistem endokrin, bukan obat-obat yang terkait saluran pernapasan.

2. Dari tiga macam katalog obat yang beredar di Indonesia, informasi yang diberikan untuk tiap obat ada lima macam (penjelasan dapat dilihat pada Tabel 1), yaitu nama obat, produsen, jenis peredaran, indeks farmakoterapi, daftar kandungan utama beserta kuantitasnya, petunjuk penggunaan, serta kemasan. Khusus dalam ISO Indonesia, petunjuk penggunaan yang diberikan terdiri dari indikasi (IN), kontraindikasi (KI), efek samping (ES), dan perhatian khusus (special precautions) (PK).

3. Kandungan ada yang memiliki nama dan struktur kimia mirip ataupun berbeda sama sekali, tetapi mempunyai efek yang sama. Daftar kandungan pada obat cukup sederhana, terdiri dari kandungan dan kuantitasnya (lihat Gambar 2). Kesulitannya adalah ejaan istilah yang 
tidak konsisten pada buku ISO Indonesia. Misalnya, "klorokina difosfat" dan "klorkina difosfat".

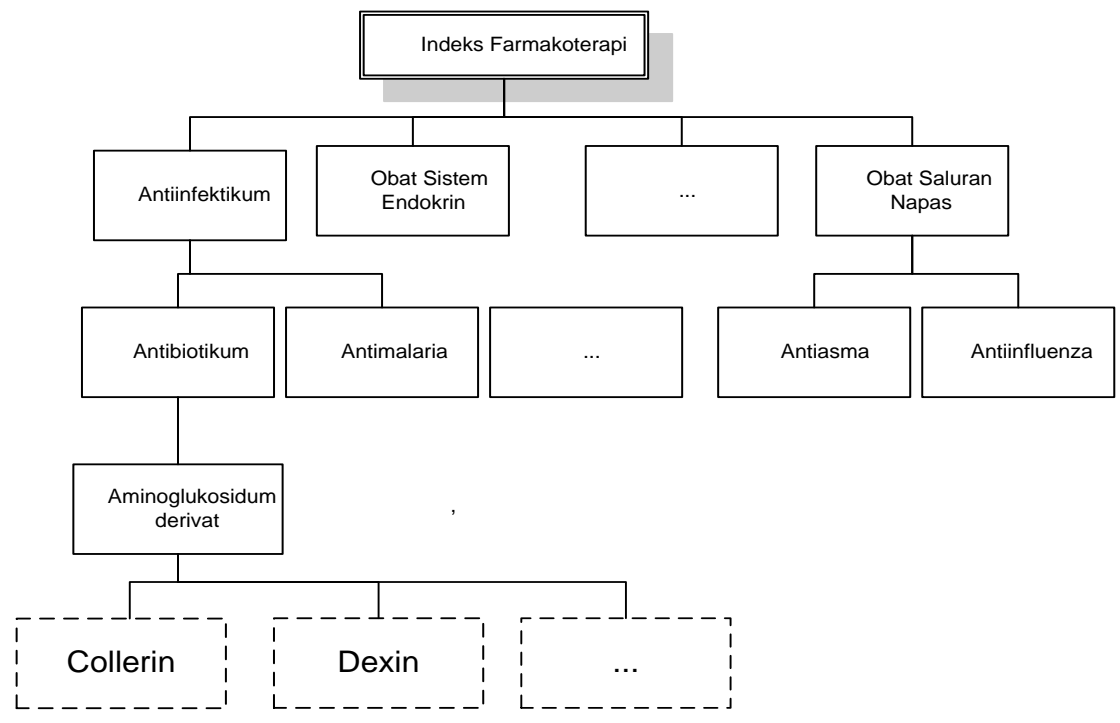

Gambar 1. Sebagian Dari Sub-Klasifikasi Indeks Farmakoterapi

Tabel 1. Keterangan Data Pada Obat

\begin{tabular}{ll}
\multicolumn{1}{c}{ Data } & \multicolumn{1}{c}{ Keterangan } \\
\hline Nama obat & Produsen obat \\
\hline Produsen & $\begin{array}{l}\text { Narkotik: hanya lewat resep dan diawasi Departemen } \\
\text { Kesehatan } \\
\text { Obat keras: hanya lewat resep dokter } \\
\text { Obat bebas terbatas: hanya didapat lewat apotek atau toko } \\
\text { obat berlisensi } \\
\text { Obat bebas: dijual bebas }\end{array}$ \\
\hline Indeks farmakoterapi & Letak (klasifikasi) obat pada indeks farmakoterapi. \\
\hline Kandungan & $\begin{array}{l}\text { Daftar kandungan beserta kuantitasnya. Kandungan utama } \\
\text { kadang disebut sebagai nama generik, terutama jika } \\
\text { kandungan utamanya tunggal atau ada kandungan yang } \\
\text { dominan. }\end{array}$ \\
\hline Petunjuk penggunaan & $\begin{array}{l}\text { indikasi } \\
\text { kontraindikasi } \\
\text { efek samping } \\
\text { catatan/perhatian khusus }\end{array}$ \\
\hline Kemasan & Informasi kemasan yang tersedia berserta harga \\
\hline
\end{tabular}

BRONDILEX Medifarma $\mathrm{K}$

Tiap tablet: Teofilina 150mg; gliserilguaiakolat $100 \mathrm{mg}$.

Tiap 5ml eliksir: Teofilina 75mg; gliserilguaiakolat $50 \mathrm{mg}$.

\section{Gambar 2. Data Untuk Kandungan Utama}

4. Indikasi biasanya saling berhubungan, misalnya penderita flu juga menderita sakit kepala, dan hidung tersumbat, atau penderita asma bronkial juga menderita batuk asma.

5. Kontraindikasi dipertimbangkan terkait dengan kondisi pasien. Misalnya menderita alergi tertentu, atau sedang hamil/menyusui. Himpunan kontraindikasi beririsan sedikit dengan indikasi. 
6. Pemilihan obat untuk pasien berdasarkan informasi kandungan dan indikasi. Penggantian obat juga memperhatikan kandungan dan indikasi. Adapun yang lebih penting adalah kandungan.

7. Informasi efek samping adalah peringatan gejala-gejala tidak enak yang mungkin akan dialami pasien jika mengonsumsi obat tersebut.

8. Untuk indikasi, kontraindikasi, dan efek samping, kebanyakan daftar yang diberikan bukan daftar yang teratur, melainkan banyak memuat elemen bahasa manusia. Selain kata-kata penghubung seperti "dan", "dengan", "maupun", atau "disertai", juga banyak ditemukan frase-frase yang memuat kata sifat dan kata kerja (Gambar 3).

\section{BRONCHOPRONT Combiphar, Mack K}

Ambroksol HCL $75 \mathrm{mg} / \mathrm{kapsul} ; 15 \mathrm{mg} / 5 \mathrm{ml}$ sirop.

Indikasi: Penyakit saluran napas akut dan kronik dengan penebalan mukus patologik misal pada inflamasi mukosa bronkial akut dan kronik (bronkitis), asthma-like bronchitis, asma bronkial dengan gangguan pengeluaran dahak, bronkiektasis maupun sebagai bantuan untuk melarutkan mukus pada inflamasi saluran rinofaringeal.

ES: Gangguan lambung, diare dan ruam kulit bisa terjadi walaupun jarang.

\section{Gambar 3. Contoh Data Untuk IN dan ES}

\subsection{Representasi Pengetahuan}

Berdasarkan hasil elisitasi pengetahuan yang disampaikan di atas, maka dirancang pengetahuan sebagai berikut:

1. Penggantian obat cuma melihat alternatif dari obat-obat yang terletak pada indeks farmakoterapi yang sama. Dengan demikian, search space pencarian lebih sempit. Pada penelitian ini, salah satu batasan basis pengetahuan yang digunakan adalah obat-obat yang berasal dari indeks farmakoterapi yang sama.

2. Data obat di dalam basis pengetahuan memuat informasi berikut.

Tabel 2. Data Obat yang Digunakan

\begin{tabular}{ll}
\hline \multicolumn{1}{c}{ Data } & \multicolumn{1}{c}{ Keterangan } \\
\hline Nama obat & Produsen obat \\
\hline Produsen & Keras/Terbatas/Bebas \\
\hline Jenis peredaran & Daftar kandungan obat \\
\hline Daftar Kandungan & Daftar indikasi obat \\
\hline Daftar Indikasi & Daftar kontraindikasi obat \\
\hline Daftar Kontraindikasi & Daftar efek samping obat \\
\hline Daftar efek samping & $\begin{array}{l}\text { Kemasan yang tersedia beserta } \\
\text { harga }\end{array}$ \\
\hline Kemasan & \\
\hline
\end{tabular}

3. Sebagian dari nama kandungan ada yang memiliki kaitan karena memiliki efek yang sama. Kandungan yang berkaitan dapat direpresentasikan sebagai graf tidak berarah, yaitu nama kandungan sebagai simpul, dan hubungan dekat sebagai busur. Contoh dapat dilihat di Gambar 4. Heuristik yang digunakan adalah bahwa obat-obat yang mengandung zat aktif atau khasiat yang sama, dihubungkan dengan busur.

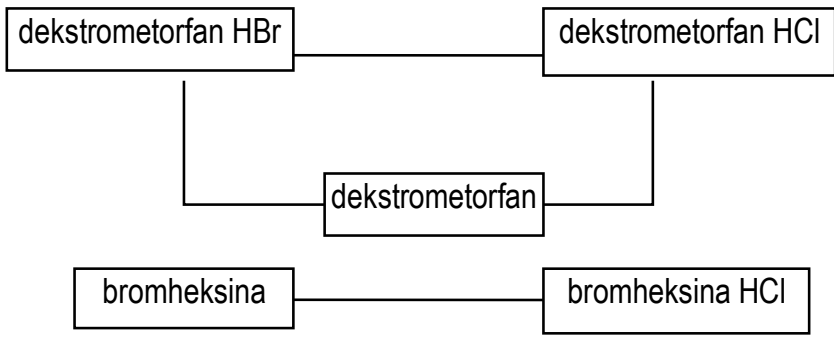

Gambar 4. Contoh Hubungan Nama Kandungan Obat

KINETIK Vol. 2, No. 3, Agustus 2017: 207-216 
Hubungan-hubungan antara kandungan pada graf ini dapat digunakan untuk menentukan kecocokan obat dari segi kandungan. Semakin dekat hubungan antara kandungan dua buah obat, maka akan semakin cocok. Dengan demikian, jarak antara simpul dapat diperhitungkan untuk menentukan tingkat kecocokan. Suatu kandungan yang sama persis (jarak simpul $=0$ ) akan memberi tingkat kecocokan yang tinggi. Semakin besar jaraknya selisihnya, maka kecocokan akan semakin rendah. Jika tidak ada hubungan, yaitu jika masing-masing kandungan terletak pada sub-graf yang terpisah, maka tidak ada kecocokan sama sekali.

4. Sebagian nama indikasi saling berhubungan. Hubungan ini dapat pula direpresentasikan dengan graf, yaitu nama indikasi sebagai simpul, dan hubungan sebagai busur (Gambar $5)$.

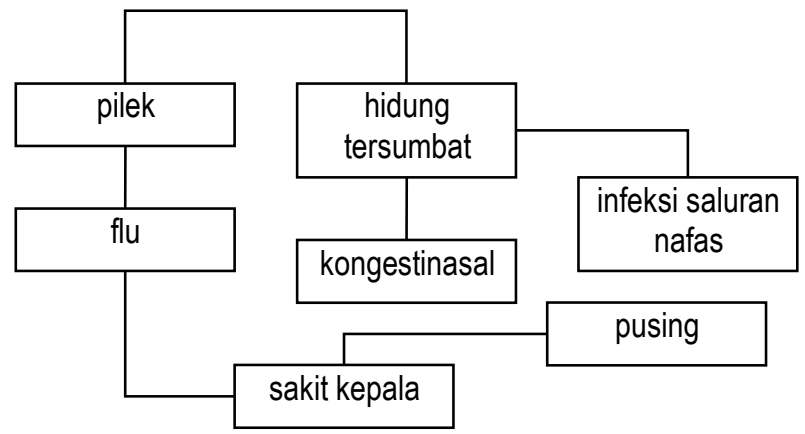

Gambar 5. Contoh Hubungan Pengetahuan Indikasi Obat

5. Dari nama kontraindikasi, sebagian kecil berhubungan. Dengan demikian, diperlukan pula representasi hubungan kontraindikasi. Maka nama kontraindikasi akan dijadikan simpul, dan hubungan antar indikasi sebagai busur.

6. Karena kandungan dianggap lebih penting daripada indikasi, maka diperlukan suatu bobot untuk menanganinya. Kandungan diberi bobot dua kali lipat daripada indikasi.

7. Sebagian nama efek samping saling berkaitan. Dengan demikian, efek samping yang saling terkait tersebut dapat dibuat dalam graf pula, nama efek samping sebagai simpul dan hubungan antar efek samping sebagai busur.

Dengan demikian ada empat buah graf yang diperlukan dalam basis pengetahuan, yaitu graf keterkaitan antar kandungan, keterkaitan antar indikasi, keterkaitan antar kontraindikasi, dan keterkaitan antar efek samping. Pengetahuan keterkaitan tersebut tidak ada di dalam katalog obat, sehingga perlu ditentukan oleh pakar. Selain itu, untuk mengatasi ketidakkonsistenan ejaan maupun penggunaan istilah, maka pakar juga perlu untuk menyeragamkan ejaan dan istilah.

\subsection{Manipulasi Pengetahuan}

Untuk mencari kecocokan kandungan, indikasi, kontraindikasi, dan efek samping digunakan graf masing-masing. Berikut adalah suatu graf keterkaitan (Gambar 6).

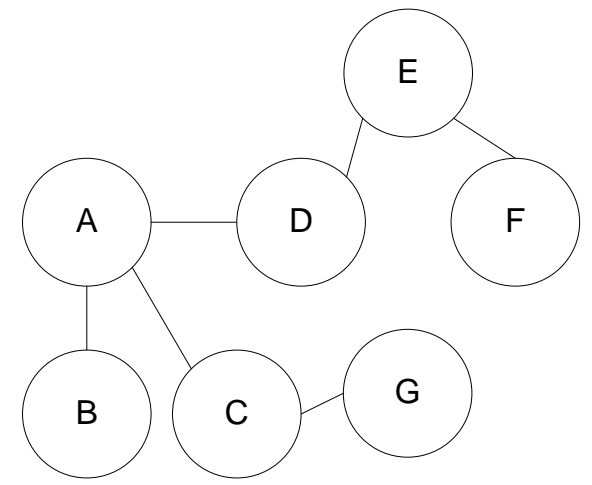

Gambar 6. Contoh Graf 
Misalkan Gambar 6 adalah graf keterkaitan antar nama indikasi. Bila ada suatu query pencarian "indikasi A", maka selain mencari obat yang mengandung indikasi A, sistem juga akan mencari obat-obat dengan indikasi yang berhubungan dengan $A$. A menjadi simpul acuan, dan disebut level 0 . Level 1 , adalah simpul-simpul berhubungan dengan $A$, yaitu $B$, $C$, dan $D$. Level selanjutnya terletak 2 langkah dari A, yaitu simpul E dan G. Sedangkan level 3, adalah F. Demikian selanjutnya. Pencarian ini dapat sedalam mungkin, yaitu sampai semua simpul yang terhubung dengan A diketahui jaraknya dari A. Dengan demikian, query "indikasi A" membuat sistem melakukan empat macam hal:

1. Pencarian obat yang terkait dengan simpul level 0 :

- Cari obat-obat yang berindikasi A

2. Pencarian obat yang terkait dengan simpul level 1:

- Cari obat-obat yang berindikasi B

- Cari obat-obat yang berindikasi C

- Cari obat-obat yang berindikasi D

3. Pencarian obat yang terkait dengan simpul level 2 :

- Cari obat-obat yang berindikasi $E$

- Cari obat-obat yang berindikasi G

4. Pencarian obat yang terkait dengan simpul level 3:

- Cari obat-obat yang berindikasi F

Hasil dari tiap sub-pencarian tersebut akan diperhitungkan berdasarkan hasil tersebut berasal dari level pencariannya simpulnya.

Tahap tadi untuk mencari kecocokan dari satu indikasi. Untuk mencari kecocokan suatu obat, perlu diproses kecocokan dari semua aspek, yaitu kecocokan segi kandungan, indikasi, kontraindikasi. Untuk lebih jelasnya, ini adalah contoh query menggunakan obat yang ada: Cari obat untuk menggantikan Bronex. Informasi yang terkandung dalam Bronex dapat dilihat di Gambar 7.

Bronex
Kandungan: bromheksina
Indikasi: batuk dahak
Kontraindikasi: tukak lambung
Efek samping: mual, muntah, diare, gangguan pencernaan
Gambar 7. Informasi Basis Pengetahuan Untuk Bronex

Untuk menyelesaikannya, tiap-tiap unsur dalam kandungan, indikasi, kontraindikasi, dan efek samping, dipecah-pecah dan dilakukan pencarian pada masing-masing. Sistem bekerja dengan cara membuat pohon pencarian untuk tiap unsur pada query. Unsur pertama adalah kandungan "bromheksina".

1. Sistem akan membuat pohon dengan akar berupa "bromheksina". Cari semua obat yang mempunyai kandungan "bromheksina". Hasil yang muncul adalah lima buah obat, yaitu Exovon, Farmavon, Hustab, Mucobron, dan Wibrom.

2. Setelah itu dicari simpul-simpul yang berdekatan dengan "bromheksina" pada graf kandungan. Di dapat "bromheksina HCl". Kandungan ini menjadi anak pencarian dari akar "bromheksina".

3. Cari obat-obat yang mempunyai kandungan "bromheksina". Ada lima obat yang memenuhi, yaitu Woods Ekspektoran, Celovon, Halmezin, Mucohexin, Solvax, dan Mosavon. Keenam obat ini dianggap memiliki kedekatan kandungan dengan salah satu kandungan dari obat Bronex, yaitu pada jarak 1. Oleh karena itu, diperlukan bobot yang lebih rendah diberikan pada enam obat ini, dibanding lima obat yang ditemukan pada langkah 1.

4. Dari "bromheksina HCl" tidak ada lagi kandungan yang dicari (level 2). Pohon pencarian dibangun dari graf kandungan, dengan bromheksina sebagai awal pencarian (Gambar 8).

\section{level 0}

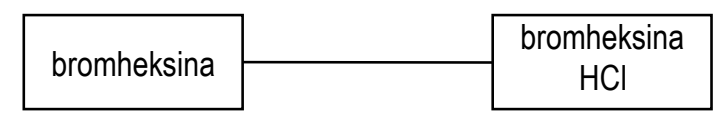

Gambar 8. Pohon Pencarian Untuk Kandungan "Bromheksina"

KINETIK Vol. 2, No. 3, Agustus 2017: 207-216 
Untuk indikasi "batuk dahak" digunakan cara yang sama. Pada Gambar 9 pohon pencarian yang dibangun sistem dari graf indikasi. "Batuk dahak" adalah awal pencarian. Sama seperti sebelumnya, semakin jauh jaraknya pencarian dari simpul acuan ("batuk dahak") maka kecocokan pencarian tersebut akan diberi bobot yang lebih kecil. Menurut perkiraan pakar, bobot yang cocok adalah sebagai Tabel 3, dengan level 2 ke atas berupa opsional, yaitu pencarian dapat saja dibatasi sampai dengan level tertentu.

Pada kontraindikasi "tukak lambung" dilakukan cara yang sama. Pada kasus ini, hanya dilakukan pada level 0 , karena "tukak lambung" tidak memiliki kaitan apa pun dengan kontraindikasi lain di graf basis pengetahuan. Sedangkan untuk query penggantian obat, unsur query yang memuat efek samping diabaikan (diberi bobot 0 ).

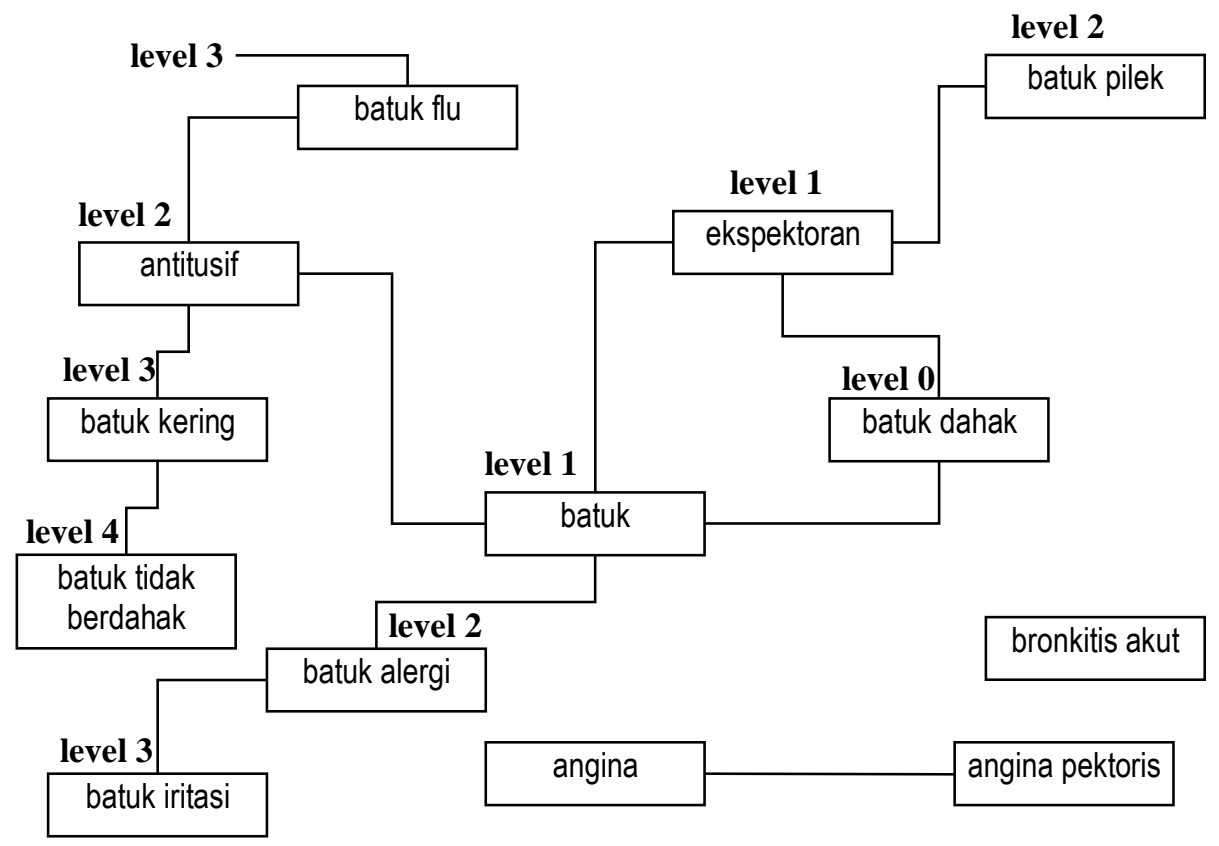

Gambar 9. Pohon Pencarian Untuk Indikasi "Batuk Dahak"

Tabel 3. Bobot Jarak Dalam Pencarian

\begin{tabular}{ll}
\hline \multicolumn{1}{c}{ Jarak } & \multicolumn{1}{c}{ Bobot } \\
\hline 0 & 1 \\
\hline 1 & 0,5 \\
\hline 2 & 0,2 \\
\hline 3 & 0,1 \\
\hline 4 & 0.05 \\
\hline
\end{tabular}

Hasil dari semua proses pencarian ini digabungkan dengan memperhitungkan bobotbobot yang digunakan. Hasilnya ditabulasi seperti Tabel 4 . Obat yang relevan harus memenuhi kriteria nilai tertentu, serta dari berbagai percobaan, pakar beranggapan bahwa batasnya adalah obat yang mempunyai nilai akumulasi yang lebih besar dari pada satu. Dengan demikian, sistem akan mengeluarkan daftar obat dari nomor urut 1-10 dari tabel.

\section{Implementasi dan Pengujian}

Untuk implementasi sistem menggunakan expert system tool CLIPS dan antarmuka pengguna dengan Borland Delphi. Ada dua modul yang dibuat, yaitu Inference Engine untuk memproses query, serta antarmuka untuk menerima dan menampilkan query dari pengguna. Untuk pengujian, digunakan:

1. Basis pengetahuan yang dibangun dari buku ISO Indonesia bagian indeks farmakoterapi 14.02 Antitusivum, Ekspektoran, Mukolitikum/obat saluran nafas.

2. Delapan query beserta daftar hasil relevannya berdasarkan pendapat pakar. 
Pengujian terdiri dari dua tahap. Pertama-tama, dilakukan pengujian terhadap semua fungsional perangkat lunak, yaitu:

1. Mencari (a) indikasi, (b) kontraindikasi, atau (c) efek samping yang diharapkan.

2. Mencari obat yang mempunyai kesamaan khasiat dengan obat lain yang dimasukkan sebagai masukan query.

Tabel 4. Hasil Pencarian Alternatif Untuk Obat "Bronex"

\begin{tabular}{|c|c|c|c|c|c|c|}
\hline No. & Nama Obat & Kand & $\ln$ & $\mathrm{KI}$ & ES & Total \\
\hline 1 & Farmavon & 1 & 0,5 & 0 & 0 & 2,5 \\
\hline 2 & Hustab & 1 & 0,5 & 0 & 0 & 2,5 \\
\hline 3 & $\begin{array}{l}\text { Woods } \\
\text { Ekspektoran }\end{array}$ & 0,5 & 1 & 0 & 0 & 2 \\
\hline 4 & Celovon & 0,5 & 1 & 0 & 0 & 2 \\
\hline 5 & Exovon & 1 & 0 & 0 & 0 & 2 \\
\hline 6 & Mucobron & 1 & 0 & 0 & 0 & 2 \\
\hline 7 & Wibrom & 1 & 0 & 0 & 2 & 2 \\
\hline 8 & Halmezin & 0,5 & 0,5 & 0 & 0 & 1,5 \\
\hline 9 & Solvax & 0,5 & 0,5 & 0 & 0 & 1,5 \\
\hline 10 & Mosavon & 0,5 & 0,5 & 0 & 0 & 1,5 \\
\hline 11 & Mucohexin & 0,5 & 0 & 0 & 0 & 1 \\
\hline 12 & $\begin{array}{l}\text { OBH } \\
\text { Minorock }\end{array}$ & 0 & 1 & 0 & 0 & 1 \\
\hline 13 & lafed & 0 & 0,5 & 0 & 0 & 0,5 \\
\hline 14 & Komix & 0 & 0,5 & 0 & 0 & 0,5 \\
\hline 15 & Corsmyl & 0 & 0,5 & 0 & 0 & 0,5 \\
\hline 16 & Metorfan & 0 & 0,5 & 0 & 0 & 0,5 \\
\hline 17 & Abstril & 0 & 0,5 & 0 & 0 & 0,5 \\
\hline
\end{tabular}

Selanjutnya dilakukan pengujian tingkat keberhasilan query pada sistem dengan menggunakan bahan pengujian. Pada tahap ini, setiap query yang diujicobakan dihitung persentase relevancy dan persentase recall. Nilai \% relevancy $100 \%$ berarti semua obat yang ditampilkan sistem adalah obat yang relevan, sedangkan nilai recall $100 \%$ berarti semua obat yang relevan berhasil ditampilkan oleh sistem.

Dari pengujian tahap I didapat bahwa semua fungsi perangkat lunak berjalan dengan benar. Dari pengujian tahap II didapat rata-rata nilai \% relevancy adalah $95,0 \%$ dan rata-rata nilai $\%$ recall adalah $87,2 \%$. Hasil pengujian yang lengkap dapat dilihat di Lampiran E.

Setelah melakukan pengujian, diketahui bahwa semua fungsi perangkat lunak sudah baik. Akan tetapi, pada pengujian pada hasil query, ada dua hal yang belum optimal. Yang pertama adalah relevancy tidak $100 \%$, yaitu adanya obat-obat yang tidak relevan atau tidak cocok yang ikut ditampilkan sistem sebagai keluaran query (butir uji nomor 4, 5, dan 8). Yang kedua adalah adanya recall tidak $100 \%$, yaitu beberapa obat yang dianggap relevan oleh pakar, tapi tidak ditampilkan oleh sistem (butir uji 1, 2, 5-8).

\subsection{Relevancy tidak $100 \%$}

lain:

Ada tiga butir pengujian yang memiliki relevancy tidak $100 \%$. Alasan-alasannya antara

1. Adanya kecocokan pada kriteria yang tidak penting. Misalnya pada butir uji 5 terdapat beberapa item yang tidak relevan. Obat tersebut terdapat pada daftar keluaran karena memiliki kecocokan kandungan dengan query, padahal kecocokan tersebut ada pada kandungan yang kurang penting. Oleh karena itu, cara untuk mengatasi masalah ini, yaitu memberi tanda atau bobot untuk tiap item mana yang dianggap lebih penting pada masukan query atau menyimpan ini pada basis pengetahuan.

2. Adanya kecocokan pada indikasi secara lemah (bukan level 0, sepeti "batuk flu" dan "demam"), serta kecocokan efek samping. Tapi cuma sebatas itu. 
4.2 Recall tidak $100 \%$ adalah

Ada enam butir pengujian yang tidak menghasilkan recall yang 100\%. Alasan utamanya

1. Tidak adanya kecocokan pada level 0 . Walaupun ada kecocokan di level yang dalam (level 1), akan tetapi hal ini tidak cukup untuk melewati nilai batas minimum agar ditampilkan sebagai hasil query. Jika nilai minimum dinaikkan, maka nilai relevancy menurun.

2. Data obat tertentu minim pada basis pengetahuan (tidak memiliki data indikasi, kontraindikasi, maupun efek samping), sehingga nama obat tersebut tidak te-retrieve

3. Graf indikasi belum dibangun dengan baik, serta kurang terhubung. Masih ada entry indikasi seperti "bersin" dan "bersin-bersin" tidak disamakan. Untuk memperbaiki permasalahan ini perlu dilakukan penelaahan serta perbaikan pada basis pengetahuannya.

\section{Kesimpulan}

Setelah merancang serta membuat sistem berbasis pengetahuan dan mengujinya, maka kesimpulan penelitian ini adalah:

1. Sistem berbasis pengetahuan dapat digunakan dalam ranah obat-obatan, khususnya obatobat bermerek dijual oleh umum, untuk mengatasi permasalahan-permasalahan yang muncul.

2. Karena query belum menghasilkan nilai relevancy yang $100 \%$, ada kemungkinan obat salah, atau tidak sesuai. Oleh karena itu, pengguna tetap perlu melihat detail hasil pencarian oleh sistem untuk menentukan obat yang dipilih. Untuk itu disarankan pengguna adalah orang yang tidak terlalu awam terhadap obat-obatan, yaitu dokter dan apoteker.

\section{Referensi}

[1] ISFI, Ed., Ikatan Sarjana Farmasi Indonesia. Informasi Spesialite Obat Indonesia, 2016.

[2] P. Parish, "Medicines: a guide for everybody," Penguin Books Ltd, 1987.

[3] Nabela Oktasari, "Perancangan dan Implementasi Sistem Informasi Database Obat Apotek Berbasis Web," Universitas Telkom, bandung, 2012.

[4] O. Purnamayudhia, "Aplikasi Sistem Informasi Penjualan Obat Di Apotek Dengan Menggunakan Metode Visual Basic 6," Journal of Engineering and Management in Industrial System (JEMIS), Vol. 3, No. 2, Pp. 87-94, 2015.

[5] M. Alfarisyi, S. Sulistiowati, Y. Maulana, "Rancang Bangun Sistem Informasi Perencanaan Persediaan Obat Dengan Metode Winter Pada Dinas Kesehatan Kota Surabaya," Jurnal Sistem informasi \& Komputer Akuntansi ((JSIKA), Vol. 3, No. 1, Pp. 152-157, 2014.

[6] J. Nasir, K. Satoto, R. Kridalukmana, "Sistem Informasi Pengelolaan Obat Di Instalasi Farmasi Dinas Kesehatan Kabupaten Pekalongan," Jurnal Teknologi dan Sistem Komputer, Vol. 2, No. 1, Pp. 71-78, 2014.

[7] M. Minarni, S. Susanti, "Sistem Informasi Inventory Obat Pada Rumah Sakit Umum Daerah (RSUD) Padang," Jurnal Momentum, Vol. 16, No. 1, Pp. 103-111, 2016.

[8] A. Nurwulandari, P. Rosa, "Sistem Pendukung Pengambilan Keputusan Pengadaan Obat Menggunakan Model Pareto ABC dan Optimasi Kualitatif (Studi Kasus: Apotik PS)," Seminar Nasional Aplikasi Teknologi Informasi (SNATI), 2013.

[9] R. Ayu P.W, H. Tanuwijaya, "Penerapan Metode Electre Dalam Sistem Pendukung Keputusan Pemilihan Supplier Obat Dan Alat Kesehatan (Studi Kasus PT Mitra Farma Anugerah Lestari Kediri)," in Proceedings of KNASTIK, 2009.

[10] P. Jackson, "Introduction to expert systems," Addison-Wesley, 1999.

[11] F. Puppe, "Programming Languages and Expert System Tools," in Springer-Verlag Berlin Heidelberg, 1993. 